\title{
A Study on Financing Efficiency of Real Estate Companies and Innovative Financing Channels
}

\author{
Yijie Zhu \\ SHU-UTS SILC Business School \\ Shanghai University \\ Shanghai, China \\ E-mail: zyj19982333@163.com
}

\author{
Xiaosong Zheng* \\ SHU-UTS SILC Business School \\ Shanghai University \\ Shanghai, China \\ E-mail: xiaosong.zheng@shu.edu.cn
}

\begin{abstract}
The real estate industry plays an imperative role in Chinese economy. However, it becomes increasingly tough for real estate companies to finance in the current market. The challenge in financing indeed brings some constraints to these enterprises and has some negative influences on the whole industry. Today real estate companies are expanding too fast, and they do not pay enough attention to the concept of "enterprise financing efficiency". However, as domestic bank loan conditions become more and more stringent, the real estate developers are in urgent need of exploring new financing channels. This paper analyses the financing efficiency of Chinese real estate companies and the traditional financing channels used by the industry in the past. By means of Data Envelopment Analysis model, this paper analyzes whether the major real estate companies utilize their financing capital efficiently and suggests some practical and innovative approaches to help enterprises better accommodate market change.
\end{abstract}

Keywords-Real estate; Financing efficiency; Financing channels; China

\section{INTRODUCTION}

The real estate industry has become the pillar industry of Chinese economy after more than twenty years ago. However, the development of real estate industry in China has experienced a period of barbaric growth, which was called 'Golden decade', and now enters into a relatively stable growth because of stringent economic policy and market imperfection.

The process of finance activities in modern business world starts from capital raising, a real estate company which generally needs to maintain the stability of the capital chain often invests a fairly large amount of its capital in the earlier stage of a project, moreover, a residential project usually has a long capital return period, so it is especially hard for real estate companies to compete with others and survive finally if they neglect the financing efficiency.

There are three factors that have contributed to creating the harsh financing situation. The first factor is Chinese government's strict control in economic policy. Ministry of Housing and Urban-Rural Development and People's Bank of China have introduced some policies which aim for enhancing financing supervision and preventing systematic financial risks since 2017. Authority wanted to see this pillar industry deleveraged and as a result, those regulations have reduced the approaches of companies in real estate industry to finance.
The second factor is the pressure of competition that comes from overseas-funded enterprises which have more mature business model and more abundant capital than domestic ones.

Last but not least, Chinese real estate industry is a diverse industry, with several companies making a huge amount of profits, some stagnating and others lagging seriously behind. It is no exaggeration to say that the number of companies that lack modernization management and far-sighted development strategies make up a large part of the total.

\section{LITERATURE REVIEW}

Yang and Li (2008) think that since the great reform and opening, especially after the mid-1990s, the real estate industry has maintained a relatively fast growth rate driven by a series of housing consumption policies in China. Real estate has made an important contribution and has become a pillar industry of the national economy [1]. Ke (2013) states that as the most basic economic unit in the country's economic system, the operation status of enterprises directly determines the speed and quality of national economic growth. The most basic premise of business operations is capital, which is the lubricant that runs through the enterprise from the establishment to the daily operation. Therefore, the quality of the financing strategy is directly related to the quality of business operations. And any enterprise that wants to develop at a high speed and grow its own strength must be properly financed. However, enterprises must undergo different stages of development in the development process, and their funding needs are different at each stage of development. Therefore, it is particularly important in today's society to have a deep understanding of the characteristics of the life cycle of a company and to find a suitable financing method [2]. He (2016) illustrates that now real estate finance has become an important part of China's national economy and plays an imperative role in the development of China's real estate industry. However, due to its rapid development, there are still many problems and hidden dangers which are gradually exposed in the recent development process [3]. Zhao, Liu and Shi (2011) claim that the great contributions of major companies in promoting market competition, improving production efficiency, optimizing industrial structure, and creating employment opportunities have become increasingly prominent in recent years. However, the asymmetry of the contribution of these enterprises to the economy is that the financing difficulties of enterprises and the low efficiency of financing have become the main bottlenecks restricting their development. [4]. Zhang (2015) shows that as a 
capital-intensive industry, the real estate industry needs a lot of money to maintain the development of the industry. However, China has adopted tightening measures for real estate bank credit, which has led to an increase in the difficulty of financing real estate enterprises. It is more difficult to adopt traditional real estate financing methods, which will seriously affect the stable development of the industry. Actively exploring new real estate financing channels to ensure their stable development is the focus of the future real estate industry [5].

\section{RESEARCH METHOD AND DATA COLLECTION}

\section{A. Definition of enterprise financing efficiency}

The definition of corporate financing efficiency mainly includes: the enterprise financing process is actually a resource allocation process expressed in the form of capital supply and demand. The financing efficiency of enterprises also represents a certain degree of financing or financing system of the enterprise. The ability and effectiveness of the investment transformation process. The higher the efficiency of corporate finance, the easier it is for social idle funds to enter the production field and the higher the financial efficiency.

This paper argues that corporate financing efficiency can be understood as the company's need to integrate the required funds at the lowest possible cost. This includes the ability of companies to make the lowest cost choices between multiple financing instruments and the ability to raise funds in a timely and sufficient manner. The financing efficiency of the enterprise is also reflected in whether the funds that the enterprise can obtain can be effectively utilized. The financing cost of the enterprise is only the lowest price that the enterprise must pay to obtain the capital. From the perspective of the enterprise, whether the funds obtained by the enterprises can be effectively utilized and whether the projects invested can be optimally determined directly determines the cost of capital and the efficiency of financing. If the investment income of the enterprise is not enough to compensate for the financing cost, even if the financing cost is low, the financing efficiency is undoubtedly low. Therefore, we define corporate financing efficiency as the ability to generate corporate value. It should include three aspects:

First, the financing efficiency of a company refers to whether the company can meet the required funds at the lowest possible cost. This includes the ability of companies to make the lowest cost choices between multiple financing instruments and the ability to raise the required funds in full and on time. Since the supply of financing instruments is determined by market conditions, the minimum income required by investors to provide capital over a certain period of time is also determined by market conditions. The minimum price that enterprises must pay to obtain capital is largely beyond the control of the enterprise. A certain risk value compensation can be given according to the degree of risk of different financing methods. Therefore, the financing efficiency of enterprises is the choice of various financing methods under the given market constraints from the perspective of enterprises themselves. The improvement of actual efficiency depends on the cooperation of market conditions. In this sense, the improvement of corporate financing efficiency is the result of the interaction between enterprises and the market.
Secondly, the financing efficiency of enterprises is also reflected in whether the funds that the enterprises can use can be effectively utilized. Corporate finance costs are simply the lowest prices that companies must pay to obtain capital. From the perspective of enterprises, whether the funds obtained by enterprises can be effectively utilized, and whether the projects invested can obtain the best benefits directly determines the financing cost and financing efficiency of enterprises. If the investment income of the enterprise is not enough to compensate for the financing cost, even if the financing cost is lower, the financing efficiency is undoubtedly low. From the perspective of the entire financing system, the inefficient use of funds by a large number of micro-subjects is inevitably unhelpful to the effective allocation of capital resources. Therefore, the concept of corporate financing efficiency also includes the profitability or value-added characteristics of the integration funds.

Third, we must look at the efficiency of corporate finance from a comparative and dynamic perspective. Under the same market conditions, whether enterprise financing is efficient can only be known through comparison. For a single enterprise, it is possible to compare the financing cost and investment income of the enterprise to obtain the distribution range of the financing efficiency of the enterprise and judge the relative financing efficiency of the enterprise; from the perspective of the overall economic efficiency of the financing system, mainly through dynamic Compare and observe whether the evolutionary trend of financing efficiency is reasonable.

\section{B. Traditional financing channels}

\section{1) Bank loan}

Asking domestic commercial banks for loans is the main financing channel for most of the real estate enterprises in China accounting for at least $60 \%$ of the funds sources of these companies. The loan method includes guaranteed loans, guaranteed mortgage loans and credit loans. The loan forms of the real estate industry include working capital loans, land reserve loans, housing developing loans and housing mortgage loans and the first two types of loan are strictly limited because of the impacts of the central bank's policies, which require that the real estate enterprises have complete credentials and no bad credit history.

Banks, who will be more standardized in credit and more rigorous in reviewing real estate projects in the foreseeable future, are working on supporting quality customers and quality projects as well as on cooperating with these customers more deeply. For strong developers, bank loans will become easier while for small and medium-sized developers, bank loans will become more and more difficult but all of these companies are supposed to try to corporate with banks more deeply in more business areas.

\section{2) Bond financing}

The issuance of bonds is also an important channel for the financing of housing enterprises. In the context of the country's stringent real estate price policy and limited domestic financing channels, the housing enterprises have generally adopted ways of overseas debt issuance and non-standard financing in previous years. 
At present, the operating mechanism of China's corporate bond market is not perfect, and there have been many cases in which corporate bonds cannot be repaid on time due to the large amounts of funds, high risks and poor liquidity of real estate projects. Therefore, the government strictly controls the approval of real estate project bonds so the threshold of bond issuance in China is quite high and too hard to implement.

\section{3) Equity financing}

Equity financing of real estate companies means that the shareholders of real estate companies are willing to sell part of the company's ownership and introduce new shareholders by increasing the capital of the company to finance and this method requires companies to establish a more comprehensive corporate legal person management system. The corporate governance structure of the company is generally composed of general meetings of shareholders, board of directors, board of supervisors and senior managers, forming multiple risk constraints and power balance mechanisms among themselves thus reducing the company's business risk.

The equity financing of real estate companies has three characteristics. The first one is that it is long-term, the funds raised through equity financing are permanent and there is no expiration date and no return is required. In addition, it is irreversible so enterprises do not need to repay the capital or interest; if investors want to get their invested capital back they need to go to look for chances in the circulation market. Last but not least, it is affordable, enterprises do not need to pay fixed dividends; whether the payment will exist and how much payment will be depending on the operation situation of the company.

\section{Investigation method}

The Data Envelopment Analysis method was created by the operations researchers A. Charnes, W.W. Cooper and E. Rhodes in 1978. The initial proposal was the production efficiency evaluation model CCR for multiple inputs and multiple outputs in the case of Constant Scale Returns (CRS) model, this model is used to study whether a production department with multiple inputs, especially with multiple outputs, is both effective and technically efficient. The model consists of the most efficient decision-making unit to form the production frontier, defining its efficiency as 1 , while the decision-making unit within its frontier boundary is considered relatively ineffective, and its efficiency value is defined between 0 and 1. In 1984, Banker, Chames, and Cooper proposed an improved version of the CRS model (VRS or BCC model) to consider the case of variable returns to scale.

\section{Empirical analysis}

This paper selects the listed Chinese real estate company in 2017 as a sample to explore financing efficiency. The data was collected from the 2017 annual report of each company and the relevant indicators were obtained from the annual report.

Based on the data availability, system feasibility, importance and comprehensiveness, economy, comparability and other principles, this paper selects total corporate assets $\left(\mathrm{x}_{1}\right)$, total shareholders' equity $\left(\mathrm{x}_{2}\right)$, and asset-liability ratio $\left(\mathrm{x}_{3}\right)$ As an input indicator under the DEA model, the net income asset ratio $\left(\mathrm{y}_{1}\right)$ and the total return on assets $\left(\mathrm{y}_{2}\right)$ are selected as output indicators.

TABLE I. REAL ESTATE COMPANIES' OPERATION STATISTICS

\begin{tabular}{|l|l|l|l|l|l|}
\hline firm & $\mathrm{y}_{1}$ & $\mathrm{y}_{2}$ & $\mathrm{x}_{1}$ & $\mathrm{x}_{2}$ & $\mathrm{x}_{3}$ \\
\hline 1 & 0.2782 & 0.0443 & 1049669258000 & 933057329000 & 0.8889 \\
\hline 2 & 0.2124 & 0.0440 & 1761752000000 & 242208000000 & 0.8625 \\
\hline 3 & 0.2114 & 0.0555 & 1165439373000 & 186673939000 & 0.8398 \\
\hline 4 & 0.0870 & 0.0380 & 128778484000 & 30816581000 & 0.7607 \\
\hline 5 & 0.2518 & 0.0247 & 623102238000 & 60638225000 & 0.9027 \\
\hline 6 & 0.1534 & 0.0983 & 645404785000 & 273543430000 & 0.5762 \\
\hline 7 & 0.2968 & 0.0567 & 189398346000 & 24632544000 & 0.8699 \\
\hline 8 & 0.1785 & 0.0732 & 362763854000 & 106178675000 & 0.7073 \\
\hline 9 & 0.1609 & 0.0802 & 574565707000 & 172422703000 & 0.6999 \\
\hline 10 & 0.0827 & 0.0271 & 235828246000 & 46794439000 & 0.8016 \\
\hline 11 & 0.2209 & 0.0917 & 57817312000 & 21771226000 & 0.6234 \\
\hline 12 & 0.1360 & 0.0608 & 307558673000 & 96746797000 & 0.6854 \\
\hline 13 & 0.1211 & 0.0397 & 222044379000 & 66443712000 & 0.7008 \\
\hline 14 & 0.1951 & 0.0662 & 151757534000 & 34270140000 & 0.7742 \\
\hline 15 & 0.1723 & 0.0258 & 106421670000 & 12224301000 & 0.8851 \\
\hline 16 & 0.1506 & 0.0630 & 43668752000 & 13047628000 & 0.7012 \\
\hline 17 & 0.3443 & 0.0955 & 298108940000 & 64893654000 & 0.7823 \\
\hline 18 & 0.1658 & 0.0971 & 163357666000 & 44176230000 & 0.7296 \\
\hline 19 & 0.1055 & 0.0595 & 191894163000 & 21614426000 & 0.6940 \\
\hline 20 & 0.1401 & 0.0780 & 69735458000 & & 0.6901 \\
\hline
\end{tabular}

This paper uses DEAP2.1 software to solve the problem of DEA model involved. According to the raw data of the sample enterprises, the relevant input and output data of 20 real estate listed companies were compiled, and 20 models were established 
respectively. Each DMU has 3 different input indicators $\mathrm{x}_{1}, \mathrm{x}_{2}, \mathrm{x}_{3}$ and 2 different output indicators $\mathrm{y}_{1}, \mathrm{y}_{2}$. Use the DEA model to solve. The calculation results are as follows:

TABLE II. CALCULATION RESULTS OF ENTERPRISE FINANCING EFFICIENCY

\begin{tabular}{|c|c|c|c|c|}
\hline firm & crste & vrste & scale & \\
\hline 1 & 0.711 & 0.808 & 0.880 & drs \\
\hline 2 & 0.560 & 0.617 & 0.907 & drs \\
\hline 3 & 0.572 & 0.614 & 0.932 & drs \\
\hline 4 & 0.339 & 0.407 & 0.833 & drs \\
\hline 5 & 0.677 & 0.742 & 0.912 & drs \\
\hline 6 & 1.000 & 1.000 & 1.000 & - \\
\hline 7 & 1.000 & 1.000 & 1.000 & - \\
\hline 8 & 0.707 & 0.759 & 0.932 & drs \\
\hline 9 & 0.728 & 0.823 & 0.884 & drs \\
\hline 10 & 0.260 & 0.288 & 0.904 & drs \\
\hline 11 & 1.000 & 1.000 & 1.000 & - \\
\hline 12 & 0.586 & 0.634 & 0.925 & drs \\
\hline 13 & 0.427 & 0.431 & 0.992 & irs \\
\hline 14 & 0.679 & 0.741 & 0.917 & drs \\
\hline 15 & 1.000 & 1.000 & 1.000 & - \\
\hline 16 & 1.000 & 1.000 & 1.000 & - \\
\hline 17 & 1.000 & 1.000 & 1.000 & - \\
\hline 18 & 0.896 & 1.000 & 0.896 & drs \\
\hline 19 & 0.573 & 0.619 & 0.924 & drs \\
\hline 20 & 0.841 & 0.855 & 0.983 & drs \\
\hline mean & 0.728 & 0.767 & 0.941 & \\
\hline \multicolumn{5}{|c|}{ Note: crste $=$ technical efficiency from CRS DEA } \\
\hline \multicolumn{5}{|c|}{ vrste $=$ technical efficiency from VRS DEA } \\
\hline \multicolumn{5}{|c|}{ scale $=$ scale efficiency $=$ crste $/$ vrste } \\
\hline
\end{tabular}

In the end, the scale of income of 20 real estate enterprises was obtained, and the scale of remuneration of enterprise units was as shown in Table below:

TABLE III. REAL ESTATE COMPANIES’ RETURN TO SCALE IN 2017

\begin{tabular}{|c|c|c|c|}
\hline & Increasing & Constant & Decreasing \\
\hline Amount & 1 & 6 & 13 \\
\hline Percentage & $5 \%$ & $30 \%$ & $65 \%$ \\
\hline
\end{tabular}

From the table, we can see that among the 20 large-scale real estate development enterprises, 6 are in the same scale, and 13 are in the stage of decreasing returns to scale and the DEA efficiency value is lower. The reason may be that the lack of development funds has constrained the further development of these enterprises and the smooth implementation of the conversion project. If these enterprises obtain more investment funds and strengthen process management when implementing transformation projects, economies of scale will make them have more output, and financing efficiency will be improved.

\section{WAYS TO IMPROVE THE FINANCING EFFICIENCY}

\section{A. Mezzanine financing}

"Mezzanine financing" this name comes from its dual characteristics of both debt financing and equity financing. Real estate developers can adjust their equity structures according to the special requirements of the raised funds, and they can also apply for loans from banks.

The method can meet the need of a company to finance before this company gets all the certificates because this method has a low requirement for a project. In addition, investors usually do not need much control of this company. The repayment 
method of mezzanine financing is more flexible compared to that of equity finance, which means mezzanine financing has lower risks of investment; the investors are more likely to exit from the target company. Therefore, this method has higher liquidity compared to private equity investment. However, mezzanine financing has one drawback, which is that the cost of financing is relatively large so banks may take measures to restrict such financing in the future.

\section{B. Asset securitization}

Securitization of real estate assets refers to the fact that investors put their funds in terms of bond-proxy into immovable properties which are managed and guaranteed by professional institutions all the way. In this way, investors can get stable financial returns efficiently.

This approach allows companies that received financing to achieve assets realization in a timely manner, diversify the financing risks, and increase the flexibility of financing. There is one disadvantage of this method is that the investment cycle is relatively long, which results to the small scale of asset securitization in China where actually only a small group of mature commercial properties adopt this method.

\section{Real Estate + Internet Finance}

The Internet finance was originally an emerging industry proposed by European countries. Its essence is to integrate the traditional financial industry with the thriving internet industry and use information technology to provide a platform for corporate finance, information exchange and other financial services. This is a new tool which relies on internet to bring revolutionary changes on the financial industry and economic development in China. Internet Finance brings both new opportunities and challenges to China's real estate enterprises

The flow of funds is the core of finance, and e-commerce can start Internet business by using information flow and providing a platform for the flow of funds. The internet finance includes e-commerce platform, crowdfunding, internet microfinance and public offering fund and private offered fund.

The internet microfinance, which is also called $\mathrm{P} 2 \mathrm{P}$ model, uses the Internet as a third-party platform to make profits by providing microfinance to other companies or individuals. Its service targets are customers with rigid demands, that is, customers who have money and customers who need loans.

The threshold for crowdfunding is relatively low, companies usually uses crowdfunding platforms to pool small sums of funds and then form pools of funds for financing. Moreover, crowdfunding is also a financing channel that independent individuals can use since putting ideas on an online platform for crowdfunding is a fast and efficient way to provide funds to achieve product realization.

The main difference between public and private funds is the modes of supervision. Public funds are funded by public offerings and its target customers are the general public while private equity funds are not publicly funded and its target customers are a small number of specialized investment professionals who can use more flexible derivatives transactions to achieve asset arbitrage. Compared to public offering fund, private offered funds is less risky because the revenue is based on absolute returns.

The advantages of the Internet financial model are reflected in the fields of big data and cost. The Internet can take the place of manual work to deal with massive amounts of information related to financing. If Internet finance is more used in real estate industry than traditional financing method, labor costs and time costs will relatively decline, operation efficiency will increase, financing procedures will be simpler and resource allocation will be more rational.

However, the Internet financial generally has high management risk and high credit risk. It is less capable of preventing and controlling risks because of its richness of information on the internet platform. Internet finance requires higher professional qualities of managers, the reason is that if the management level of Internet companies cannot keep up with the pace of its development, the operational stability will decrease which results to the constraint of its development.

\section{CONCLUSION AND Discussion}

The exploration of financing channels for real estate enterprises in China has received much attention. On the one hand, the state has stricter requirements for the financing of real estate enterprises; on the other hand, the development of China's financial market is not mature enough to meet the needs of fast-growing real estate enterprises.

This paper analyses the current problems that Chinese real estate companies face and concludes that because of increasingly strict government policies and stringent bank loan conditions, real estate enterprises will be well-advised to pay more attention to the financing efficiency and try to diversify their financing channels instead of sticking to the old ones.

The above innovative financing methods can have the following impacts on real estate companies: First, they can improve financing efficiency due to their large-scale of financing, large amounts of funds and the its financing maturity is changeable so as to maintain the flexibility of business operations. Secondly, financing costs will be reduced which can save interest expenses and then reduce financial pressure. Thirdly, these methods can reduce external influences by keeping the stability of funding sources and optimize the capital structure by adjusting the proportion of liabilities. Finally, in these ways, real estate enterprises can activate stock capital, release the value of its internal assets, make these companies more in line with regulatory requirements as well as promote the diversification of real estate financing channels. 


\section{REFERENCES}

[1] Y. Yang \& P. Li, "Analysis of financing channels of real estate enterprises in China", Proceedings of the Symposium on Building a Harmonious International Economic and Trade Relations in Northeast Asia, 2008:5.

[2] Y. Ke, "Thinking of financing strategies in different periods of the enterprise", Proceedings of the 2013 Annual Conference of China Foreign Economic and Trade Accounting Society, $2013: 10$.

[3] X. He, "The main problems and countermeasures of real estate finance in China”. Today Fortune Magazine, Today's Fortune Magazine, 2016:2.

[4] M. Zhao, P. Liu \& A. Shi, "Research on financing efficiency of high-tech SMEs in China based on DEA method", Chinese Enterprise Operations Research [2011(1)], 2011:8.

[5] Y. Zhang, "Analysis of the status quo and development trend of real estate financing channels", Proceedings of the Conference on Decisions Information, 2015:1.

[6] N. Hu, "Research on the relationship between real estate financial structure and real estate economic growth", Proceedings of the 9th China Management Science Academic Conference, 2007: 5.

[7] L. Zhang, "Investment and financing strategy in the process of enterprise growth-Based on the perspective of enterprise life cycle theory", Proceedings of the 2007 Annual Meeting of the China Enterprise Management Research Association,2007:10.

[8] C. Wu, "DEA Analysis of the Effectiveness of Enterprise Knowledge Integration", Proceedings of the 9th China Management Science Academic Conference, 2007: 4.

[9] S. Zhou \& Y. Xie, "Analysis of Core Competitiveness of Real Estate Enterprises Based on Value Chain", Business Research, 2005(14):135-138.

[10] J. Guo \& Q. Xu, "Research on the Financing Risk Prevention of Real Estate Enterprises in China", Finance and Accounting Research, 2014(03): $52-54+76$

[11] D. Guo \& G. Zeng, "Analysis on the Breakthrough and Innovation of Real Estate Enterprise Financing Channels", Economic Research Guide, 2008(10): 80-83.

[12] Tonghuashun Financial Database, Data center of HK Stocks, Financial indicator Analysis, 2018(7). 